OPEN ACCESS

Edited by:

Alexandra Kravchenko, Michigan State University,

United States

Reviewed by:

Carsten W. Mueller,

Technische Universität München,

Germany

Bertrand Guenet,

Centre National de la Recherche

Scientifique (CNRS), France

*Correspondence:

Teamrat A. Ghezzehei

taghezzehei@ucmerced.edu

Specialty section:

This article was submitted to Soil Processes,

a section of the journa

Frontiers in Environmental Science

Received: 03 March 2018 Accepted: 08 June 2018 Published: 19 July 2018

Citation:

Jian M, Berhe AA, Berli M and Ghezzehei TA (2018) Vulnerability of Physically Protected Soil Organic Carbon to Loss Under Low Severity

Fires. Front. Environ. Sci. 6:66. doi: 10.3389/fenvs.2018.00066

\section{Vulnerability of Physically Protected Soil Organic Carbon to Loss Under Low Severity Fires}

\author{
Mathew Jian ${ }^{1}$, Asmeret Asefaw Berhe ${ }^{1}$, Markus Berli ${ }^{2}$ and Teamrat A. Ghezzehei ${ }^{1 *}$ \\ ${ }^{1}$ Life and Environmental Sciences Department, School of Natural Sciences, University of California, Merced, Merced, CA, \\ United States, ${ }^{2}$ Division of Hydrologic Sciences, Desert Research Institute, Las Vegas, NV, United States
}

Soil aggregate degradation during medium and high severity fires is often identified as the main mechanism that leads to loss of soil organic matter (SOM) due to fire. Low severity fires, however, are considered not to cause aggregate degradation assuming that temperatures $<250^{\circ} \mathrm{C}$, as occurring during low-severity burns, have only limited effects on the stability of the soil organic binding agents. Recent studies suggest that low severity burns may cause soil aggregate degradation due to rapid vaporization of soil pore water that can induce pressure on the soil aggregates beyond their yield stress. Such pressuredriven degradation of soil aggregates may expose physically protected organic carbon to decomposition. Our study investigated the effect of a low-severity fire on soil organic matter (SOM), water extractable organic $\mathrm{C}$, and $\mathrm{N}$ as well as respiration for two initial soil moisture conditions undergoing three "heating regimes" using aggregates from a California forest and a Nevada shrubland soil. We found that initially moist soil aggregates that were rapidly heated up degraded the most, showing increased cumulative carbon mineralization when compared to aggregates that were not heated, aggregates that were dry before being heated, and initially moist soil aggregates that were slowly heated. Our results suggest that exposure of previously physically protected organic carbon within the soil aggregates to oxidative conditions was the most likely cause of increased rates of decomposition of organic matter after low-severity burns. Additionally, we show that for a shrubland soil, aggregates with relatively low organic carbon content, low severity burns increased cumulative carbon mineralization. We hypothesized that this was due to decomposition of cytoplasmic material from lysed microbes. Our results suggest that low severity burns can accelerate decomposition of soil organic carbon (SOC) protected in soil aggregates.

Keywords: aggregation, fire, soil carbon, decomposition, water extractable OM

\section{INTRODUCTION}

Fire is a major global controller of ecosystem processes exerting chief controls on soil processes through combustion of organic materials, production, and deposition of charred necromass (or pyrogenic carbon) and influencing several soil physico-chemical conditions (DeBano et al., 1998; Certini, 2005; Araya et al., 2016). The impact of medium-to-high-severity fires (with soil surface temperature of $>250^{\circ} \mathrm{C}$ ) on soil processes and properties is widely recognized and has been the 
subject of many previous studies (DeBano et al., 1977; Certini, 2005; Carroll et al., 2007; Johnson et al., 2007; Knicker, 2007). Araya et al. (2016, 2017) performed systematic tests of temperature effect on physical properties of five different soils from the western Sierra elevation transect. They subjected the soils to six levels of maximum temperature $\left(150-650^{\circ} \mathrm{C}\right)$ and observed statistically significant deterioration in water stable aggregation only for soils heated to $350^{\circ} \mathrm{C}$ or more. The decline in aggregate stability in the studies of Araya et al. (2016, 2017) was closely related to loss of carbon from macro- and micro-aggregate size classes. In contrast, samples that were subjected to $150-250^{\circ} \mathrm{C}$ heating did not exhibit loss of bulk soil organic carbon (SOC) nor water stable aggregation. Other field studies of low severity burns have also documented only a little or no effect on soil properties and processes immediately after the fires (DeBano et al., 1977, 1998; Mataix-Solera et al., 2002, 2011; O’Dea, 2007; Arcenegui et al., 2008; Jordan et al., 2011).

However, long-term observations of soil structure following low severity fires have revealed substantial loss of aggregate stability and porosity. These degradations in soil structure often are accompanied by reduced infiltrability and significantly increased susceptibility to wind and water erosion. For example, Úbeda and Bernia (2005) monitored aggregate stability of forest soils in northeastern Spain that experienced low, intermediate, and high severity burns. They noted that immediately after the burns, there was a consistent increase in aggregate stability across the entire burn severity spectrum, but aggregate stability in all the sites (including the low severity sites) was considerably below the control site after 8 months and remained so 2 years after the burn. Similar observations were made after a controlled, low-severity burn conducted in August 2009 at Upper Gleason Creek Watershed in the eastern Great Basin (Nevada). These observations showed a protracted process of soil structure degradation both under the shrub canopy and shrub interspaces (Chief et al., 2012; Kavouras et al., 2012). Under shrub canopies, soil structure degraded from moderate subangular blocky structure to coarse weak subangular blocky immediately after the fire and broke down further in the ensuing 9 months to a structureless soil. In interspaces, soil structure degraded from a moderateto-strong coarse subangular blocky structure with hard dry consistency to a weak-to-medium subangular blocky structure with soft dry consistency immediately after the burn. The interspace soil became structureless 13 months after the burn. The above observations suggest that the mechanisms of soil structure degradation under low-intensity burns are characteristically different from medium-high severity fire conditions, and that effect of low-severity of fires on soil aggregation and dynamics of aggregate protected carbon in soil necessitates an in-depth investigation on effect of fires on these variables.

In previous study, we hypothesized that soil aggregates subjected to low severity burns can be degraded due to transient elevated gas-phase pressure caused by rapid vaporization of pore water (Albalasmeh et al., 2013). To simulate rapid heating of surface soils, we placed soil aggregates in preheated muffle furnace for $30 \mathrm{~min}$. These were contrasted with aggregates that were gradually heated to the same maximum temperature at $3^{\circ} \mathrm{C} / \mathrm{min}$. Aggregates subjected to rapid heating in $125-175^{\circ} \mathrm{C}$ range exhibited significantly lower water stability compared to aggregates heated to the same maximum temperature at a slow rate, although both sets of aggregates did not show measurable loss of SOM. Albalasmeh et al. (2013) was the first study to suggest the importance of rapid vaporization of pre water for soil aggregate degradation during low severity burns (Urbanek, 2013). In a follow up study (Jian et al., 2018), we showed that the gas-phase pressure directly measured inside moist aggregates rises to a level that is comparable to the tensile strength of the aggregates.

It follows then that deterioration of soil aggregates by the previously-described mechanism may also adversely impact physical protection of SOM from decomposition and leaching (Tisdall, 1996; Hassink and Whitmore, 1997; Piccolo and Mbagwu, 1999; Balesdent et al., 2000; Chenu and Plante, 2006; Schmidt et al., 2011). The mechanisms of physical protection of SOM within aggregates can include: adsorption of organic compounds on to solid mineral surfaces, with pockets of water-saturated pores where SOM decomposition is limited by oxygen availability, and complex pore geometry and tortuosity of diffusion pathways that limit diffusion of water, oxygen, and organic substrates to soil decomposers. SOM occluded within aggregates accounts for large fraction of the total SOM and tends to have significantly longer turnover time than bulk SOC (Flessa et al., 2008). Historically, the effects of low severity fires on soils on aggregation as well as carbon and nitrogen dynamics has received very little attention (Moghaddas and Stephens, 2007).

The present study was designed to test a follow up hypothesis that weakening of soil structure during low-severity burns leads to accelerated loss of SOM previously physically protected within aggregates. Specifically, we hypothesized that leaching loss of water extractable organic carbon (WEOC) and decomposition rate of SOC would be higher in soils subjected to rapid heating, albeit to $<200^{\circ} \mathrm{C}$. To test these hypotheses we conducted simulated burn experiments that can induce weakening of soil aggregates by rapid vaporization of pore water and compared with control samples in terms of (a) quantity and quality of water extractable $\mathrm{C}$ and $\mathrm{N}$ and (b) the rate of carbon mineralization in the burned samples with control treatments.

The often overlooked physical and biogeochemical impact of low severity fires is likely to cover a substantial proportion of the land exposed to natural and controlled fires. For example, half of the combined wildfire and prescribed burn area reported in the U.S. between 1984 and 2016 was characterized as low in intensity (time-averaged energy flux) and severity (degree of ecological effects) (Eidenshink et al., 2007; Keeley, 2009; MTBS, 2017) and appears to have been gradually increasing in aerial proportion over the last three decades (Jian et al., 2018). Similarly, about $80 \%$ of the burned area in Russia's boreal forest is characterized as low severity surface fire (Conard et al., 2002). 


\section{MATERIALS AND METHODS}

\section{Soil Sampling}

Soil samples were collected from two distinct ecosystems that experience low severity fires in the western United States. The first soil was a sandy loam (Ultic Haploxeralfs, Holland series) collected from an undisturbed pine forest in Mariposa County, United States. The second soil was a loam (Calcic Petrocalcids, Purob series) collected from an unburned shrubland near Las Vegas, Nevada (adjacent to the burn boundary of the Carpenter 1 Fire) in Clark County, United States. In the subsequent sections of this paper, these soils will be referred to as forest and shrubland soils, respectively.

Soil samples were collected from 0 to $10 \mathrm{~cm}$ depth, which represents the soil layer that is most impacted by low severity surface fires. The samples, were air dried and separated into three aggregate size fractions $(0.25-1,1-2$, and $2-4 \mathrm{~mm})$ by dry sieving. The separated fractions were then homogenized by gentle manual mixing. Characteristics of the soils are provided in Table 1.

\section{Simulated Burn Experiments}

Low severity fire can affect dynamics of SOM via chemical, biological, or physical processes. Exposure of soil to elevated temperature can desiccate organic (e.g., sticky extracellular polymeric substances) and inorganic molecules (e.g., clay and carbonates) that bind soil particles together (Tisdall and Oades, 1982). This chemical transformation of binding agents can degrade aggregates thereby exposing physically protected SOM. Likewise, the population and community structure of soil microorganisms can be altered by high temperature in a way that can alter rate of mineralization. In this study, we were primarily concerned with additional mechanical disturbance of aggregates by rapid rise in the gas phase pressure, which arises when wet soil is exposed to direct source of heat (e.g., flame).

The effect of low severity burn on soil aggregates was simulated by placing aggregates equilibrated to a matric potential of $-30 \mathrm{kPa}$ ("field capacity") inside muffle furnace pre-heated to $175^{\circ} \mathrm{C}$. The samples were exposed to this temperature for 30 min, which is equivalent to the time it takes for small dry logs to burn (Stoof et al., 2010). Direct placement in pre-heated furnace mimics the rapid temperature rise of surface soil that exposed to flame from burning biomass. These aggregates were expected to experience rapid rise in pneumatic pressure due to rapidly vaporizing pore water, which momentarily exerts destabilizing stress as it escapes (Albalasmeh et al., 2013; Jian et al., 2018). This form of heat treatment is referred to as "Rapid Burn" (RB) in the remainder of this paper. To distinguish the mechanical effect of the gas pressure from other biological or chemical effects due to elevated temperature (e.g., lysing of soil microbes or desiccation of organic molecules, respectively) we designed two additional heating experiments. In the first, which will be referred to as "Slow Burn" (SB), aggregates were prepared in identical manner as in the $\mathrm{RB}$ treatment but placed inside muffle furnace at room temperature $\left(\sim 25^{\circ} \mathrm{C}\right)$ before being heated at $3^{\circ} \mathrm{C} / \mathrm{min}$ until the furnace reached $175^{\circ} \mathrm{C}$ (which takes $\sim 1 \mathrm{~h}$ ). The samples were then kept at $175^{\circ}$ for $30 \mathrm{~min}$
TABLE 1 | Characterization of studied soils (mean \pm standard error, where $n=$ 3-5.

\begin{tabular}{lcccc}
\hline Soil & $\begin{array}{c}\text { Aggregate } \\
\text { size }(\mathbf{m m})\end{array}$ & $\begin{array}{c}\text { Field capacity } \\
\text { water content } \\
\mathbf{( g / g )}\end{array}$ & $\begin{array}{c}\text { Organic carbon } \\
\mathbf{( \% )}\end{array}$ & Clay (\%) \\
\hline Forest & $0.25-1$ & $0.328 \pm 0.001$ & $5.73 \pm 0.07$ & $11.55 \pm 4.90^{*}$ \\
& $1-2$ & $0.252 \pm 0.003$ & $4.67 \pm 0.10$ & \\
& $2-4$ & $0.286 \pm 0.012$ & $3.58 \pm 0.10$ & \\
Shrubland & $0.25-1$ & $0.165 \pm 0.002$ & $1.25 \pm 0.02$ & $21.05 \pm 0.86$ \\
& $1-2$ & $0.145 \pm 0.001$ & $0.70 \pm 0.01$ & \\
& $2-4$ & $0.120 \pm 0.002$ & $0.53 \pm 0.01$ &
\end{tabular}

Clay content is expressed in mean \pm standard deviation, where $n=4$ for forest soil and $n=3$ for shrubland soil). ${ }^{*}$ Value previously reported by Albalasmeh et al. (2013).

so that exposure to the peak temperature is comparable to the RB treatment. However, the aggregates in the SB treatment receive higher total heat energy input and longer exposure ( $\sim 60 \mathrm{~min})$ during the temperature rise phase. In a third heating experiment initially air-dried samples (matric potential of $\sim 30$ $\mathrm{MPa}$ ) were subjected to the same heating regime as for the $\mathrm{RB}$ treatment. This treatment, which will be referred to as "Slow Rapid Burn" (SRB) exposes the aggregates to the same total amount of heat energy and duration as the main RB treatment, but avoids the generation of potentially disruptive high water vapor pressure by keeping the initial moisture content of the aggregates at a minimum. As an overall control, untreated aggregates (denoted as UB) were kept at room temperature. Aggregates in the SB and DRB treatments were expected to exhibit chemical and biological effects on the quantity and quality of water extractable organic matter as well as the rate of mineralization. While aggregates in the RB treatment will exhibit additional physical effect of aggregate disruption by elevated pore pressure.

\section{Moisture Equilibration of Soil Aggregates}

The water content of the aggregates at field capacity ws determined using pressure plate apparatus (Soilmoisture Equipment Corp, Goleta CA). Briefly, triplicate sets of $5 \mathrm{~g}$ of soil aggregate samples from each soil type and aggregate size were placed on pre-wetted porous ceramic plates inside a pressure plate apparatus. Then, the aggregates were wetted by lightly spraying a fine mist of water and subsequently by capillary action from a thin film of water on top of the porous plates. Then, the aggregates were equilibrated to a matric potential of -30 $\mathrm{kPa}$ ("field capacity") for $24 \mathrm{~h}$. Subsequently, the samples were transferred to aluminum weighing dishes and their gravimetric water content was determined by drying them in an oven at $105^{\circ} \mathrm{C}$ for $24 \mathrm{~h}$. The gravimetric water contents of the soil aggregates are summarized in Table $\mathbf{1 .}$

\section{Leaching of Water Extractable Organic Matter}

The goal of this experiment was to test whether low severity burn frees leachable organic matter previously protected inside stable aggregates. To achieve this, we measured the quantity and quality 
of water extractable organic matter from aggregates subjected to the four treatments described above: RB, SB, DRB, and UB.

Prior to the heating treatments, $10 \mathrm{~g}$ of soil aggregates from the $2-4 \mathrm{~mm}$ size fraction were added to stainless steel cups with plastic lids. Water was slowly added onto the SB and $\mathrm{RB}$ treatment of soil aggregates by lightly spraying with a fine mist of water to get the water content of the soil aggregates to field capacity. The cups were then capped and the samples were allowed to equilibrate for $16 \mathrm{~h}$. Then, the aggregates were subjected to the four burn treatments as described in Section Simulated Burn Experiments.

Soil aggregates were transferred onto pre-saturated porous plates in a Tempe Cell set-up (Soilmoisture Equipment Corp, Goleta CA). The aggregates were wetted by lightly spraying with a fine mist to avoid slaking. Then, additional $40 \mathrm{~mL}$ of deionized water was slowly added into the Tempe Cell and the aggregates were allowed to soak for $15 \mathrm{~min}$. Afterwards, $10 \mathrm{kPa}$ of pressure was applied for $10 \mathrm{~min}$ to extract the soil leachate from the Tempe Cell. The leachate was then further filtered through a $0.45 \mu \mathrm{m}$ filter paper and stored in the dark at $4^{\circ} \mathrm{C}$ for a maximum of 14 days. The water extractable organic $\mathrm{C}$ and $\mathrm{N}$ concentrations (WEOC and TN, respectively) in the leachate were measured using a Shimadzu TOC-Vcsh analyzer.

Chemical composition of the soil leachate was analyzed using a Thermo Scientific Evolution 3000 Ultraviolet-Visible (UVVIS) spectrophotometer Absorbance was measured between 200 and $560 \mathrm{~nm}$, using ultrapure water as blank. Measurements were performed using a quartz cell with $1.25 \mathrm{~cm}$ path length. The specific UV absorbance at $254 \mathrm{~nm}\left(\right.$ SUVA $\left._{254}\right)$ was used to determine whether there were changes in aromaticity of the WEOC in the burned samples. SUVA 254 was calculated by normalizing the specific absorbance coefficient at $254 \mathrm{~nm}$ by the WEOC concentration. The ratio of absorption at $250-365 \mathrm{~nm}$ $\left(A_{250}: A_{365}\right)$ was used to estimate the average molecular size of the WEOC in the soil leachate as high molecular weight. Molecules absorb light at longer wavelengths than at shorter wavelengths (Santos et al., 2016).

\section{Mineralization of Organic Matter-Incubation Experiment}

The goal of the heating experiments was to test whether degradation of aggregate stability by elevated steam pressure generated by rapid vaporization of pore water can lead to higher rates of SOC mineralization. Prior to the heating treatment, $5 \mathrm{~g}$ of soil aggregates in the $0.25-1 \mathrm{~mm}$ and the $1-2 \mathrm{~mm}$ size fraction per sample were placed into $50 \mathrm{~mL}$ glass vials with caps equipped with rubber septa. Then, the aggregates were subjected to the four burn treatments as described in Section Simulated Burn Experiments.

The samples were then wetted to field capacity with a micropipette, capped and allowed to equilibrate for $24 \mathrm{~h}$. Afterwards, the caps were removed and the vials were covered with Parafilm ${ }^{\circledR}$ and incubated at $21^{\circ} \mathrm{C}$ in the dark for over 2 months. The vials were weighed every 3-7 days and water was added to maintain the initial moisture content. Gas samples were pulled from the forest sample vials on days $1,2,3,5,7,10,13$,
$17,21,26,31,37,43,50,57$, and 65 by capping the vial for $3 \mathrm{~h}$ and extracting $15 \mathrm{~mL}$ of gas through the septa on the vial caps. Gas samples were pulled from the shrubland samples in a similar fashion on days 1, 2, 3, 5, 7 10, and 13. Gas samples were also collected in subsequent days for the shrubland samples, but $\mathrm{CO}_{2}$ flux rates were within measurement errors of the gas chromatographer used to analyze the samples. The samples were then analyzed on a gas chromatograph (Shimadzu GC-2014) fitted with a thermal conductivity detector to determine the concentration of carbon dioxide.

The change in SOC stock due to mineralization can be described using a first order kinetics model (Jenny, 1980).

$$
\frac{d C}{d t}=-\kappa \mathrm{C}
$$

Where, $C$ (C-mass/ soil-mass) is the quantity of mineralizable $C$ and $k(1 /$ time $)$ is the rate constant of mineralization. Assuming the soil remained under constant environmental conditions, the equation can be solved to provide an exponential decay of soil C content

$$
C=C_{0} e^{-\kappa t}
$$

Where, $C_{0}$ is the initial stock of the biologically active $C$ pool. The $\mathrm{CO}_{2}$ efflux at time $t$ can be given as

$$
C_{\mathrm{CO}_{2}}=C_{0}\left(1-e^{-\kappa t}\right)
$$

The linearity of the model permits expansion to multiple $\mathrm{C}$ pools that exhibit differing dynamics.

$$
C_{\mathrm{CO}_{2}}=\sum_{i=1}^{N} C_{0, i}\left(1-e^{-\kappa_{i} t}\right)
$$

A two-pool model appropriate for the rapid-burned soils will be introduced in subsequent section. The unknown parameters can be estimated by fitting the model to experimental data.

\section{Statistical Analysis}

Comparisons of burn treatments for WEOC concentration, SUVA $_{254}$, and A250:A365 in the soil leachate, and initial mineralizable $\mathrm{C}$ pool and rate constant of mineralization of for the $\mathrm{CO}_{2}$ measurements were performed using one-way ANOVA, and pairwise comparison of burn treatments was performed using Tukey's test at $p<0.05$ significance level when applicable. All analyses were conducted using $\mathrm{R}$ statistical software ( $\mathrm{r}-$ project.org).

\section{RESULTS}

\section{Water Extractable Organic $\mathbf{C}$ and $\mathbf{N}$ Concentrations}

The mean WEOC concentration of the leachate from the UB forest aggregates was $3.38 \pm 0.18 \mathrm{mg}^{-C ~ g-S^{-1}}$ (Figure 1). All three heating treatments ( $\mathrm{BB}, \mathrm{SB}$, and $\mathrm{DRB})$ significantly increased the WEOC concentration when compared to the leachate from the UB aggregates $(P<0.05)$. Moreover, WEOC of the SB and DRB treatments were significantly higher than that 


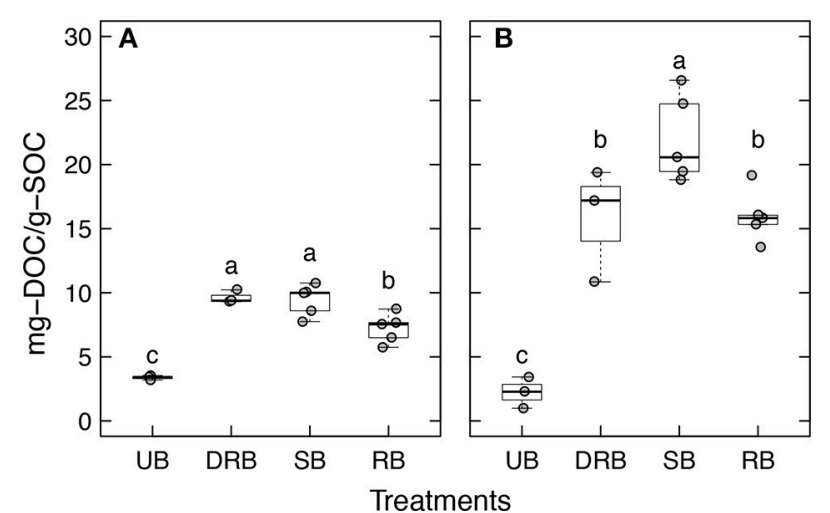

FIGURE 1 | Water extractableorganic carbon $\left(\mathrm{mg} \mathrm{L}^{-1}\right)$ in the soil leachate from unburned (UB), dry rapidly burned (DRB), slowly burned (SB), and rapidly burned (RB) soil aggregates from (A) forest soil and (B) shrubland soil. Different letters represent significantly different means as determined from Tukey's HSD Test $(P<0.05)$.

of the RB treatment $(P<0.05)$. Overall, heat treatment increased the WEOC concentration by a factor of $\times 2.1-\times 2.8$ relative to the UB treatment.

The mean WEOC concentration of the leachate in from UB shrubland aggregates was $2.23 \pm 1.22 \mathrm{mg}-\mathrm{C} \mathrm{g-SOC}^{-1}$. The WEOC concentrations for the $\mathrm{DRB}, \mathrm{SB}$, and $\mathrm{RB}$ treatments were all significantly higher $(P<0.05)$ than for UB by factors of $\times 7.1$, $\times 9.88, \times 7.17$, respectively. The SB treatment yielded significantly higher WEOC than the DRB and RB treatments as well.

\section{C:N Ratios of Leachate and Aggregates}

The C:N ratios of the water extractable organic matter and the aggregates subjected to the four treatments are shown in Figure 2. The $\mathrm{C}: \mathrm{N}$ ratios of the leachates were significantly $(P<0.05)$ higher in the burned samples $(\mathrm{SB}, \mathrm{DRB}$, and $\mathrm{RB})$ compared to UB samples for both the forest and shrubland soils (Figures 2A, B, respectively). In addition, in the forest soils, the C:N ratio was significantly $(P<0.05)$ higher for the rapidly burned $(\mathrm{RB})$ aggregates comparted to the dry-rapidly burned (DRB) and slow burned (SB) aggregates (Figure 2A). However, there were no significant differences between the burned samples of the shrubland soils (Figure 2A).

There were no significant differences in C:N ratio of the SOM remaining in the forest aggregates subjected to the four burn treatments (Figure 2C). For the shrubland aggregates, however, $\mathrm{RB}$ caused a decrease in $\mathrm{C}: \mathrm{N}$ ratio of the aggregates compared to the UB aggregates. But there were no other significant differences among the burned samples ( $\mathrm{SB}, \mathrm{DRB}$, and $\mathrm{RB}$ ) or between the $\mathrm{DRB}$ and $\mathrm{SB}$ to the UB aggregates (Figure 2D).

\section{Specific Ultraviolet Absorbance of Leachate}

SUVA $_{254}$ of UB treatment of forest soil was $1.26 \pm 0.03 \mathrm{~L}$ $\mathrm{mgC}^{-1} \mathrm{~m}^{-1}$ (Figure 3A). The DRB treatment of forest soil was not significantly different than the UB treatment $(P>0.05$, $\left.\mathrm{SUVA}_{254}=1.02 \pm 0.12 \mathrm{~L} \mathrm{mgC}^{-1} \mathrm{~m}^{-1}\right)$. The RB and SB treatment

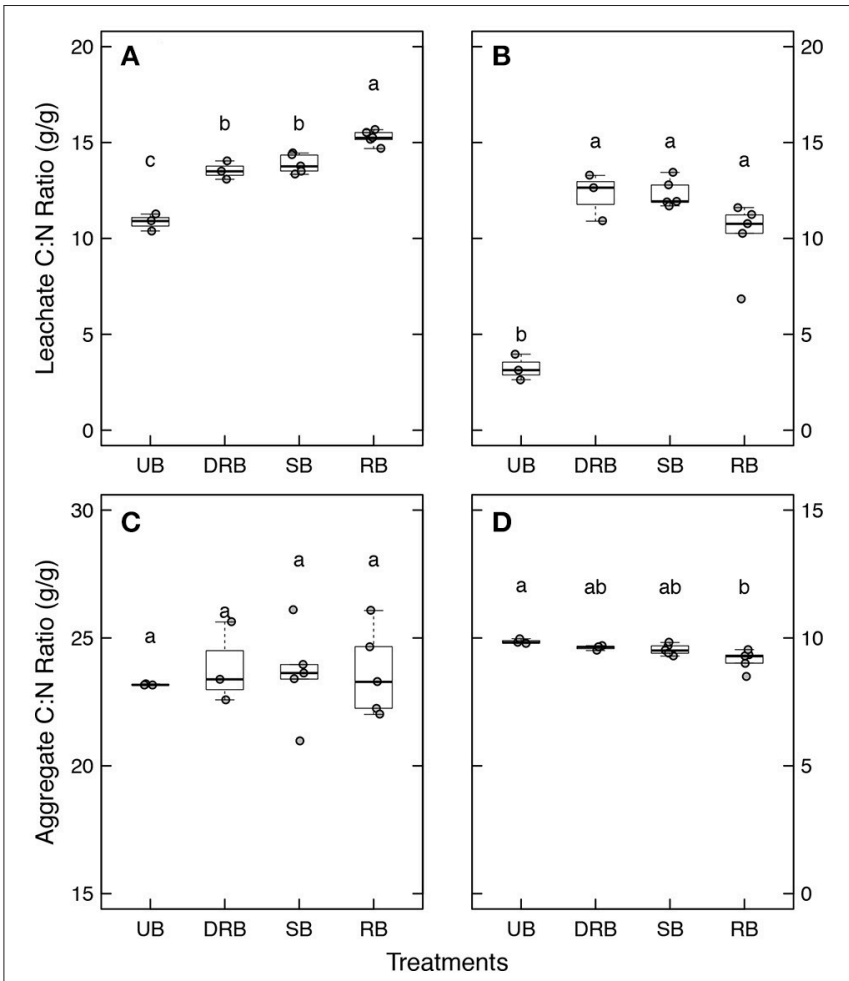

FIGURE 2 | Carbon to Nitrogen ratio (C:N) of the water extractable organic matter $(\mathbf{A}, \mathbf{B})$ and the whole aggregates $(\mathbf{C}, \mathbf{D})$ for the forest $(\mathbf{A}, \mathbf{C})$ and shrubland (B,D) aggregates.

had $\mathrm{SUVA}_{254}$ of $0.92 \pm 0.03$ and $0.88 \pm 0.03 \mathrm{~L} \mathrm{mgC}^{-1} \mathrm{~m}^{-1}$, respectively. The $\mathrm{SUVA}_{254}$ values for $\mathrm{RB}$ and $\mathrm{SB}$ treatment were significantly lower than the UB treatment $(P<0.05)$, but neither significantly differed from the DRB treatment $(P>0.05)$.

SUVA $_{254}$ of UB treatment of shrubland soil was $1.51 \pm 0.11 \mathrm{~L}$ $\mathrm{mgC}^{-1} \mathrm{~m}^{-1}$ (Figure 3B). The DRB, RB, and SB treatments had DOC concentrations of $0.82 \pm 0.00,0.56 \pm 0.07$, and 0.59 $\pm 0.05 \mathrm{~L} \mathrm{mgC}^{-1} \mathrm{~m}^{-1}$, respectively. All three treatments had SUVA $_{254}$ significantly lower than the UB treatment $(P<0.05)$. None of the three treatments had $\mathrm{SUVA}_{254}$ that significantly differed from each other $(P>0.05)$.

\section{Average Molecular Size of WEOC}

The heating treatments did not appear to have a significant effect on the average molecular size of SOC in the forest soil leachate (Figure 3C). A decrease in $\mathrm{A}_{250}: \mathrm{A}_{365}$ ratio indicates an increase in average molecular sizes. This appears to be the trend for RB and SB treatment in the shrubland soil (Figure 3D) with $A_{250}: A_{365}$ values of $5.9 \pm 1.2$, and $6.2 \pm 1.8$, respectively, and the $\mathrm{UB}$ treatment with an $\mathrm{A}_{250}: \mathrm{A}_{365}$ value of $15.9 \pm 6.0$. However, none of the burn treatments had an average molecular size of WEOC that significantly differed from each other $(P>0.05)$.

\section{$\mathrm{CO}_{2}$ Evolution}

Figures 4, 5 show the cumulative $\mathrm{CO}_{2}$-C loss over the course of the $\mathrm{CO}_{2}$ measurements for the individual forest and shrubland soil samples, respectively. Each individual sample was shown in 


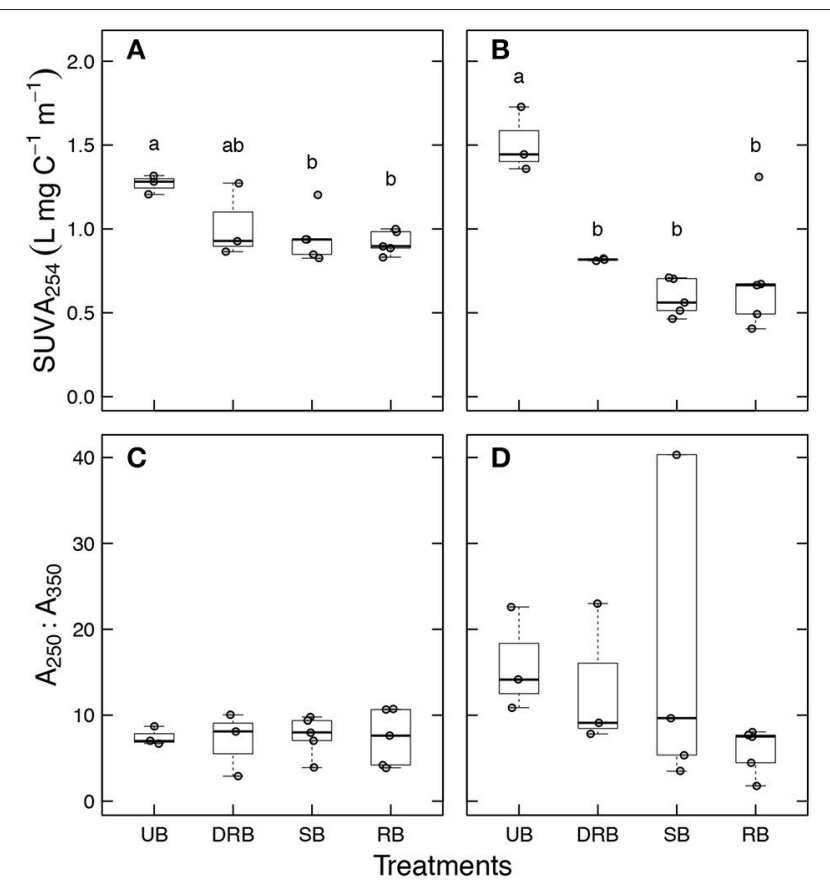

FIGURE 3 | SUVA254 (top row) and $\mathrm{A}_{250}$ : $\mathrm{A}_{365}$ (bottom row) in the soil leachate from unburned (UB), dry rapidly burned (DRB), slowly burned (SB), and rapidly burned $(R B)$ soil aggregates from $(\mathbf{A}, \mathbf{C})$ forest soil and $(\mathbf{B}, \mathbf{D})$ shrubland soil. No significant differences $A_{250}: A_{365}$ were found between burn treatments. Different letters represent significantly different means in SUVA254 as determined from Tukey's HSD Test $(P<0.05)$.

order to highlight the variability in respiration between replicates. Analysis of the cumulative $\mathrm{CO}_{2}-\mathrm{C}$ loss and rate constant of mineralization is shown in the succeeding paragraphs.

The RB of forest soil exhibits distinct two-pool pattern, indicated by the arrows in Figure 4. The second pool of carbon appears to have delayed onset of mineralization. To capture this bimodality

$$
C_{\mathrm{CO}_{2}}= \begin{cases}C_{0,1}\left(1-e^{-\kappa t}\right) & t<\mathrm{t}_{X} \\ C_{0,1}\left(1-e^{-\kappa t}\right)+C_{0,2}\left(1-e^{-\kappa\left(t-t_{X}\right)}\right) & t \geq \mathrm{t}_{X}\end{cases}
$$

Where, $t_{X}$ denotes the onset of mineralization in the secondary pool. The initial mineralizable $\mathrm{C}$ in both pools is $\mathrm{C}_{0}$ is $C_{0}=$ $C_{0,1}+C_{0,2}$. To minimize the degrees of freedom of the fitted model, both pools were assumed to have identical decay rate. The fitted delayed onset of rapid mineralization $\left(t_{X}\right)$ ranged between of $21.1 \pm 2.4$ and $19.9 \pm 1.8$ days for soil aggregates of size $0.25-1$ and $1-2 \mathrm{~mm}$, respectively. All the remaining $\mathrm{CO}_{2}$ evolution datasets were individually fit with single-pool linear decomposition model, Equation (3).

$\mathrm{C}_{0}$ of the UB treatment of forest soil with aggregate size from $0.25-1 \mathrm{~mm}$ was $1,988.1 \pm 158.5 \mu \mathrm{gC} \mathrm{g} \mathrm{soil}^{-1}$. The DRB and SB treatment of forest soil with aggregate size $0.25-1 \mathrm{~mm}$ had $\mathrm{C}_{0}$ of $2,229.2 \pm 192.7$ and $1,432.7 \pm 112.0 \mu \mathrm{gC}$ soil $^{-1}$, respectively. Neither of these samples showed $\mathrm{C}_{0}$ values that significantly differed from the UB treatment. The $\mathrm{RB}$ treatment has $\mathrm{C}_{0}=$ $3,884.6 \pm 716.7 \mu \mathrm{gC} \mathrm{g}$ soil $^{-1}$, which significantly differed from the other three treatments $(P<0.05)$. Similar results were found for the forest soil with aggregate sizes ranging from 1 to $2 \mathrm{~mm}$ in size $(P<0.05)$. The ratio of the biologically available pool of carbon to the total carbon pool $\left(\mathrm{C}_{0}: \mathrm{C}_{\mathrm{a}}\right)$ follows the same trend (Table 2) as $\mathrm{C}_{0}$ to the treatments.

$\mathrm{C}_{0}$ of the UB treatment of shrubland soil with aggregate size from 0.25 to $1 \mathrm{~mm}$ was $34.1 \pm 9.1 \mu \mathrm{gC} \mathrm{g} \mathrm{soil}^{-1}$. The DRB sample had $\mathrm{C}_{0}$ that did not significantly differ from the UB treatment $\left(68.3 \pm 13.6 \mu \mathrm{gC} \mathrm{g}\right.$ soil $\left.^{-1}, P>0.05\right)$. The $\mathrm{SB}$ and $\mathrm{RB}$ samples had $\mathrm{C}_{0}$ values of $99.3 \pm 18.2$ and $93.8 \pm 9.3 \mu \mathrm{gC} g$ soil $^{-1}$, respectively. The $\mathrm{SB}$ and $\mathrm{RB}$ treatments had $\mathrm{C}_{0}$ that were significantly higher than the UB treatment $(P<0.05)$. Neither of the samples significantly differed from the DRB treatment. For the shrubland soil with aggregate size from 1-2 mm, none of the treatments significantly differed each other $(P>0.05,67.0$ $\pm 14.3,46.7 \pm 5.0,62.1 \pm 7.2,47.9 \pm 2.9 \mu \mathrm{gC} \mathrm{g}$ soil $^{-1}$ for the $\mathrm{UB}, \mathrm{DRB}, \mathrm{SB}$, and $\mathrm{RB}$ treatment, respectively). The ratio of the biologically available pool of carbon to the total carbon pool $\left(\mathrm{C}_{0}: \mathrm{C}_{\mathrm{a}}\right)$ follows the same trend (Table 2$)$ as $\mathrm{C}_{0}$ to the treatments.

The decay rate of the active $\mathrm{C}$ pool $(k)$ of the UB treatment of forest soil with aggregate size from $0.25-1 \mathrm{~mm}$ was 0.048 $\pm 0.003 \mathrm{day}^{-1}$ (Table 2). The DRB, SB, and RB treatments had $\mathrm{k}$ values of $0.051 \pm 0.002,0.052 \pm 0.004$, and 0.035 $\pm 0.001 \mathrm{day}^{-1}$, respectively. None of the three treatments significantly differed from the UB treatment $(P>0.05)$, but the RB treatment significantly differed from the DRB and SB treatment $(P<0.05)$. The UB treatment of forest soil with aggregate size from 1 to $2 \mathrm{~mm}$ was $0.053 \pm 0.006$ day $^{-1}$. The $\mathrm{DRB}$ and $\mathrm{SB}$ treatment did not significantly differ from the UB treatment $\left(P>0.05,0.049 \pm 0.007 \mathrm{day}^{-1}\right.$, and $0.040 \pm 0.003$ day $^{-1}$, respectively). The RB treatment significantly differed from the UB treatment $\left(P<0.05,0.035 \pm 0.004\right.$ day $\left.^{-1}\right)$, but did not significantly differ from the DRB and SB treatment $(P>$ $0.05)$.

The decay constant $k$ of the UB treatment of shrubland soil with aggregate size from 0.25 to $1 \mathrm{~mm}$ was $0.290 \pm$ 0.032 day $^{-1}$. The DRB and SB treatments had $k$ values of $0.328 \pm 0.053$, and $0.173 \pm 0.016 \mathrm{day}^{-1}$, respectively. Both of these treatments did not significantly differ from the UB treatment. The $\mathrm{RB}$ treatment had $k=0.450 \pm 0.037 \mathrm{day}^{-1}$, which was significantly higher than the UB treatment $(P$ $<0.05)$, but was not significantly higher than the DRB treatment $(P>0.05)$. A similar trend is observed for shrubland soil with aggregate size from 1 to $2 \mathrm{~mm}$. However, DRB treatment differed significantly from the UB treatment $(P<$ $0.05)$.

\section{DISCUSSION}

\section{Water Extractable Organic Matter Quantity and Quality}

The increase in the concentration of WEOC in leachate across all of the burn treatments when compared to the UB control is consistent with previous soil heating studies. For example, Santos et al. (2016) and Choromanska and DeLuca (2002) saw an increase in WEOC when burning 


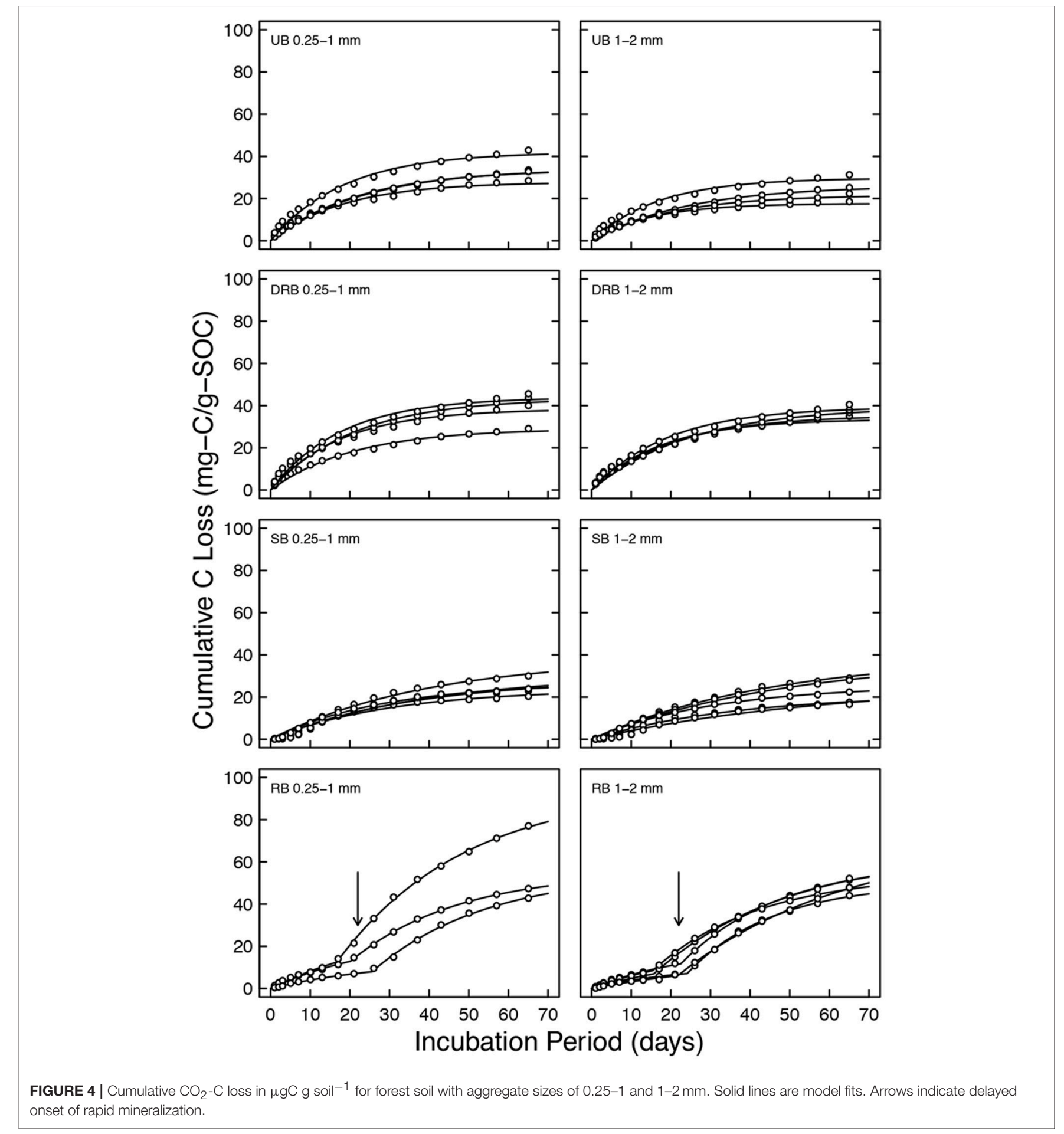

soils at around $150-250^{\circ} \mathrm{C}$. Increase in WEOC concentration have been seen in burns as high as $400^{\circ} \mathrm{C}$ (Guerrero et al., 2005). Previous studies have suggested that the increase in WEOC in burned soil samples is attributed to soluble organic compounds derived from the lysis of microbial cells at such temperature (Serrasolsas and Khanna, 1995; Santos et al., 2016).
These C:N ratio of leachates results are consistent with the $\mathrm{CO}_{2}$ evolution data we reported. Aggregates from the forest soil experienced substantial disruption during $\mathrm{RB}$, which lead to release of previously occluded SOM by leaching (Figure 3) and delayed but higher rate of $\mathrm{CO}_{2}$ release (Figures 4, 6). Relatively faster loss of $\mathrm{N}$ vs. $\mathrm{C}$ could also lead to higher $\mathrm{C}: \mathrm{N}$ ratio. But, considering the multiples line of evidence 


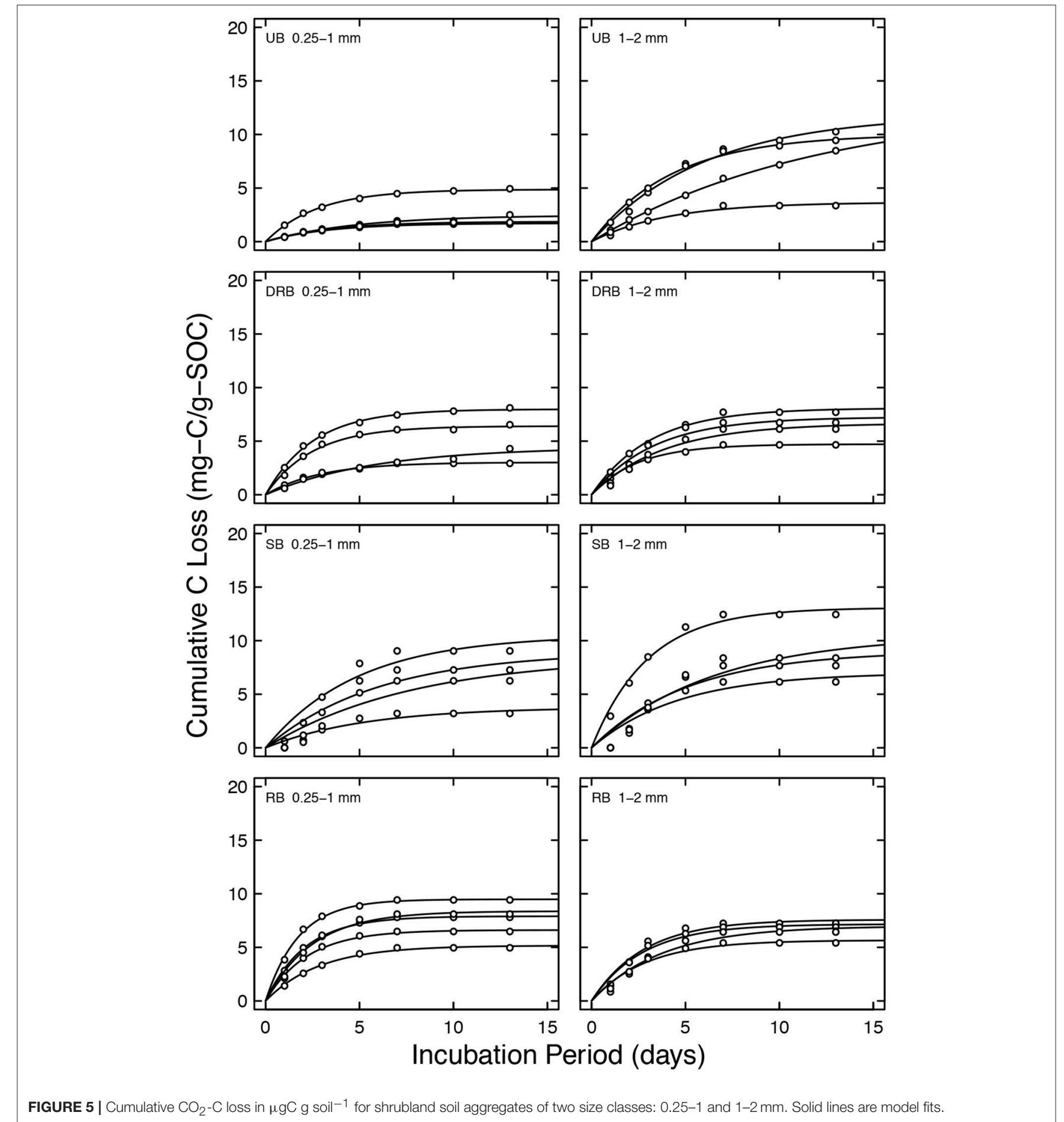

for aggregate breakdown, high rate of $\mathrm{CO}_{2}$ flux post-burn, and the C:N of the leachate, it is more plausible that the observed increase in C:N ratio of leachate post-burn is due to release of microbially-processed organic matter due to aggregate disruption.

$\mathrm{C}: \mathrm{N}$ ratio of the aggregates. This further supports the observation that rapid burn of moist soils liberates mobile and easily decomposable SOM that does not remain in noticeable quantity after the incubation period, but does not have significant effect on the OM that remains associated with soil minerals physically (inside smaller aggregates) or chemically (through sorptive interactions). Many of these microbial derived organic compounds can include oxygenated (such as carbohydrates and proteins) and aliphatic groups. These microbial derived organic 
TABLE 2 | $\mathrm{C}_{0}: \mathrm{C}_{a}$ [the ratio of the biologically available carbon pool to the total carbon pool $\left(\mathrm{C}_{\mathrm{a}}\right)$ ] of unburned (UB), rapidly burned dried (DRB), rapidly burned (RB), and slowly burned (SB) soil aggregates from forest soil with aggregate sizes $0.25-1$ and $1-2 \mathrm{~mm}$, and shrubland soil with aggregate sizes $0.25-1 \mathrm{~mm}$ and $1-2 \mathrm{~mm}$.

\begin{tabular}{|c|c|c|c|c|c|c|}
\hline \multicolumn{7}{|c|}{ Treatment } \\
\hline & Soil & Aggregate size (mm) & UB & DRB & SB & RB \\
\hline \multirow[t]{4}{*}{$\mathrm{C}_{0}: \mathrm{C}_{\mathrm{a}}$} & Forest & $0.25-1$ & $3.54 \pm 0.29$ & $3.75 \pm 0.21$ & $2.53 \pm 0.24$ & $7.01 \pm 1.26$ \\
\hline & & $1-2$ & $2.19 \pm 0.21$ & $3.59 \pm 0.12$ & $2.37 \pm 0.36$ & $5.97 \pm 0.46$ \\
\hline & Shrubland & $0.25-1$ & $0.27 \pm 0.07$ & $0.55 \pm 0.11$ & $0.77 \pm 0.13$ & $0.71 \pm 0.06$ \\
\hline & & $1-2$ & $0.90 \pm 0.18$ & $0.65 \pm 0.07$ & $1.00 \pm 0.08$ & $0.69 \pm 0.04$ \\
\hline \multirow[t]{4}{*}{$\mathrm{k}\left(\right.$ day $\left.^{-1}\right)$} & Forest & $0.25-1$ & $0.046 \pm 0.003$ & $0.051 \pm 0.002$ & $0.052 \pm 0.004$ & $0.035 \pm 0.001$ \\
\hline & & $1-2$ & $0.053 \pm 0.006$ & $0.049 \pm 0.003$ & $0.040 \pm 0.004$ & $0.035 \pm 0.004$ \\
\hline & Shrubland & $0.25-1$ & $0.290 \pm 0.032$ & $0.328 \pm 0.053$ & $0.173 \pm 0.016$ & $0.450 \pm 0.037$ \\
\hline & & $1-2$ & $0.183 \pm 0.038$ & $0.322 \pm 0.031$ & $0.189 \pm 0.018$ & $0.336 \pm 0.023$ \\
\hline
\end{tabular}
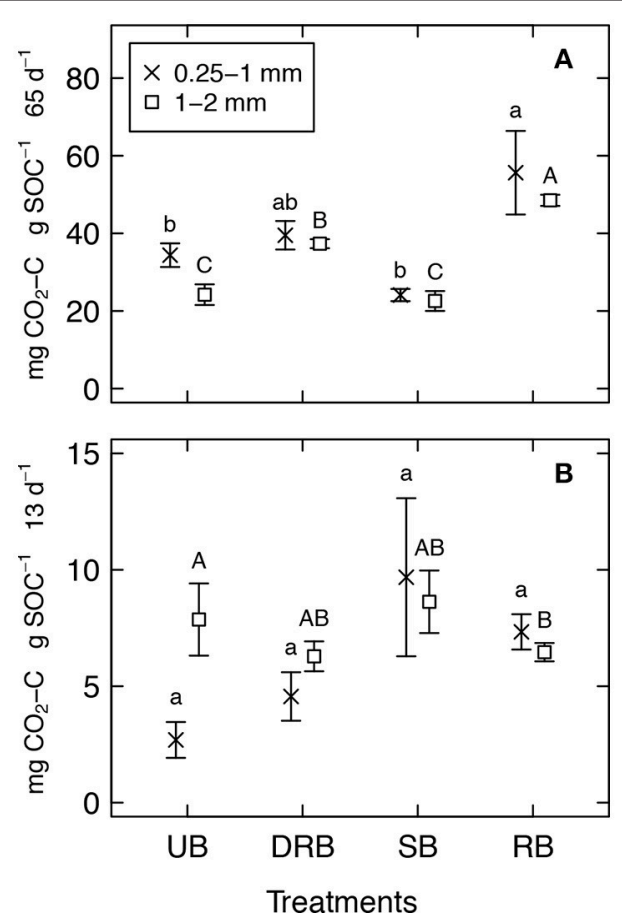

FIGURE 6 | Cumulative SOC loss from unburned (UB), rapidly burned dried (DRB), rapidly burned (RB), and slowly burned (SB) soil aggregates from forest soil (A) and shrubland soil (B). Different letters represent significantly different means, as determined from Tukey's HSD Test $(P<0.05)$, among aggregates in the $0.25-1 \mathrm{~mm}$ (lower case letters) and 1-2 $\mathrm{mm}$ (upper case letters) size classes.

compounds may explain the decrease in $\mathrm{SUVA}_{254}$ (aromaticity) in the burned treatments of the soil samples. Our results from the UV-Vis analyses are consistent with previous studies that showed that SUVA $_{254}$ decreased when soils were burned between 150 and $250^{\circ} \mathrm{C}$ (Santos et al., 2016). Generally, the existence of aromatic compounds in burned soil samples comes from enrichment of existing aromatic compounds or formation of new aromatic compounds from the thermal decomposition of existing organic matter. However, this generally occurs when soils are burned at above $300^{\circ} \mathrm{C}$ (González-Pérez et al., 2004). As there is probably little to no addition of aromatic compounds into the dissolved state of the OC, while the addition of fresh, presumably labile, microbial derived organic compounds diluted the pre-existing aromatic component of WEOC, and thus causing a decrease in SUVA $_{254}$.

The average apparent molecular size of the WEOC in the leachate did not significantly differ from the UB control samples. This result differed from a previous study in which WEOC from soils heated to $150-250^{\circ} \mathrm{C}$ significantly increased average molecular size (i.e., higher $\mathrm{A}_{250}: \mathrm{A}_{365}$ ) (Santos et al., 2016). In their study, they suggested that heating samples at those temperatures resulted in small-size molecules undergoing polymerization reactions that resulted in larger molecules. It is also possible that smaller molecular size WEOC are preferentially lost when heated between those temperatures, resulting in a pool of carbon enriched with higher molecular size compounds. However, in the Santos et al. (2016) study the soil samples were heated at the maximum temperature for $1 \mathrm{~h}$, whereas we heated our samples at the maximum temperature for $30 \mathrm{~min}$. Such thermal degradation and/or polymerization of WEOC may be time duration dependent, or even moisture dependent as shown by the increase in average molecular weight of WEOC in the SB and $\mathrm{RB}$ treatment of the shrubland soil. However, the differences in average molecular weight of the $\mathrm{SB}$ and $\mathrm{RB}$ treatment were not significantly different than the UB control treatment. Since the average molecular weight does not differ amongst the treatments, it can be inferred that the WEOC diffuses within the soil pore water at relatively the same rate assuming that pore sizes and geometry remain the same. Diffusion and/or physical accessibility of organic substrate to microorganisms is an important factor in decomposition of the substrate as most soil microbial processes require water (Balesdent et al., 2000). It is also possible that there were changes in the average apparent molecular size of the WEOC in the leachate for the $\mathrm{SB}$ and $\mathrm{RB}$ sample when compared to the UB samples of the shrubland soil, but it was not apparent in the statistical analysis since there were large variability in the UB and DRB samples.

In conclusion, both the forest and shrubland soils had higher WEOC concentration for all three burn treatments when compared to the UB control treatment. The increase 
in WEOC is likely from biodegradable cytoplasmic organic compounds from the lysis of microbial cells. Moreover, the average molecular weight of the WEOC in the burned treatments do not differ from each other nor when compared to the UB treatment, therefore the WEOC should diffuse at relatively the same rate to microbes for decomposition. These observations indicate that the burned treatments should have higher decomposition and respiration of $\mathrm{CO}_{2}$ over a course of an incubation experiment since there is more WEOC to decompose.

\section{$\mathrm{CO}_{2}$ Measurements in Forest Soil}

For both the forest soil with aggregate sizes $0.25-1$ and 1$2 \mathrm{~mm}$, the total respiration of $\mathrm{C}$ for the $\mathrm{DRB}$ and $\mathrm{SB}$ treatment did not significantly differ from the UB treatment for the respective sizes (Figures 4, 6A), even though both of those treatments were shown to have significantly higher amounts of WEOC in the $2-4 \mathrm{~mm}$ sized aggregates. The only treatment to have significantly higher total respiration of $\mathrm{C}$ was the $\mathrm{RB}$ treatment. This is likely linked to the microscopic breakdown of the soil aggregates from the stress induced by the rapid vaporization of soil pore water as proposed by Albalasmeh et al. (2013) and Jian et al. (2018). Aggregated soils are known to have higher tortuosity (Horn and Smucker, 2005) and more complex soil pore geometries that limit diffusion pathways for microbes to have access to OC for respiration (Scow and Alexander, 1992; Balesdent et al., 2000). The degradation of soil aggregation by rapidly vaporized soil pore water from the low severity burn likely contributed to the decrease in tortuosity and complex soil pore geometries within the RB treatment of forest soil. This likely allowed the soil microbes to have easier access to the WEOC within the soil aggregates.

This is also evident as the RB treatments took a considerable amount of time $\left(t_{2}\right.$ of $21.1 \pm 2.4$ and $19.9 \pm 1.8$ days for soil aggregates of size $0.25-1$, and $1-2 \mathrm{~mm}$, respectively) until increased $\mathrm{CO}_{2}$ flux from the secondary pool commenced. Initially, the rapidly vaporized water slightly weakened the soil aggregate but did not fully break up the soil aggregate to expose physically protected OC. After some time, the soil aggregates break and weaken more to expose the previously physically protected OC. This is consistent with the longterm study made on the soil structure of a shrubland in the eastern Great Basin in Nevada after a controlled, low severity burn was conducted in August 2009 (Chief et al., 2012; Kavouras et al., 2012). Five days after the burn, the soil structure degraded slightly from a moderate subangular blocky structure to coarse weak subangular blocky structure. After around 9 months, the soil structure broke down further to a structureless soil. In another long-term study, the aggregate stability of forest soils from northeastern Spain that experienced a low severity burn was shown to increase immediately after the burn (Úbeda and Bernia, 2005). This was attributed to desiccation of inorganic cementing agents. However, after 8 months the aggregate stability decreased significantly when compared to unburned soil. Both of these study sites, and our findings, highlight the importance of how the degradation of soil aggregates by rapidly vaporized soil pore water during low severity burns can take considerable amount of time.

The first order decay constant $(k)$ across all treatments was relatively unchanged when compared to the UB control treatment. However, $k$ was slightly lower in the RB treatments, which meant that the $\mathrm{OC}$ in the $\mathrm{RB}$ treatments decay at a slower rate. This is probably due to the pool of $C$ being accessed to decomposition in the $\mathrm{RB}$ treatment being mostly particulate OC (POC). POC is generally the form of OC that is occluded within soil aggregates, and are known to be less labile and decomposable than free and loose organic matter (Christensen, 2001). This further highlight that the soil aggregates are degrading for the RB treatment, since the soil decomposers in the $\mathrm{RB}$ treatment are able to access the pool of $\mathrm{C}$ within the soil aggregates that the soil decomposers in the other treatments are not able to access.

\section{$\mathrm{CO}_{2}$ Measurements in Shrubland Soil}

For the shrubland soil with aggregate size $1-2 \mathrm{~mm}$, there were no differences in total respiration of $\mathrm{C}$ across all the treatments. One possible explanation for no difference in respiration could be that the total amount of organic carbon was very small. The TOC content in the shrubland aggregates of $1-2 \mathrm{~mm}$ in size is $0.70 \pm 0.01 \%$, whereas the TOC content for the forest aggregates of size $0.25-1$ and 1$2 \mathrm{~mm}$, and the shrubland aggregates of size $0.25-1 \mathrm{~mm}$ are $5.73 \pm 0.07,4.67 \pm 0.09$, and $1.25 \pm 0.02 \%$, respectively (Table 1). Since the shrubland aggregates of size $1-2 \mathrm{~mm}$ had such low amount of OC, the addition of DOC in the form of microbial lysis may not have contributed too much to additional respiration.

\section{CONCLUSION}

This study highlights the important effects that low severity burn may have on carbon mineralization rate of soil aggregates from two distinct ecosystems. For the forest soil, with high degree of aggregation, low severity burns can rapidly vaporize soil water thereby inducing mechanical stresses that cause soil disaggregation over time. This leads to liberation of previously, physically protected SOC, thus increasing the amount of carbon mineralized. We also showed that for a shrubland soil with low degree of aggregation and OC content, low severity burns can induce microbial lysis. The lysis of microbes can release biodegradable cytoplasmic organic compounds, which can also increase carbon mineralization in the shrubland soil. Results from both of these distinct ecosystems highlight that low severity burns may affect the geochemistry of soil aggregates, in particular SOM composition and content, leading to SOM loss and eventually aggregate degradation as reported in literature for weeks to months after a fire. Low severity fires were so far considered to have little effects on soil structure due to relatively low temperature and duration of the fire. Therefore, these results warrant further investigations of these types of fires onto soil properties, as low severity burns constitute 
the majority of fires in the United States and there are limited numbers of studies on these types of fires on soil aggregation.

\section{AUTHOR CONTRIBUTIONS}

MJ was a graduate student who conducted this work as part of his MS thesis. TG, AB, and MB were co-PIs of a proposal that funded

\section{REFERENCES}

Albalasmeh, A. A., Berli, M., Shafer, D. S., and Ghezzehei, T. A. (2013). Degradation of moist soil aggregates by rapid temperature rise under low severity fire. Plant Soil 362, 335-344. doi: 10.1007/s11104-012-1 408-z

Araya, S. N., Fogel, M. L., and Berhe, A. A. (2017). Thermal alteration of soil organic matter properties: a systematic study to infer response of Sierra Nevada climosequence soils to forest fires. Soil 3, 31-44. doi: 10.5194/soil-3-31-2017

Araya, S. N., Meding, S. M., and Berhe, A. A. (2016). Thermal alteration of soil physico-chemical properties: a systematic study to infer response of Sierra Nevada climosequence soils to forest fires. Soil 2, 351-366. doi: 10.5194/soil-2-351-2016

Arcenegui, V., Mataix-Solera, J., Guerrero, C., Zomoza, R., Matalx-Beneyto, J., and Garcia-Orenes, F. (2008). Immediate effects of wildfires on water repellency and aggregate stability in Mediterranean calcareous soils. Catena 74, 219-226. doi: 10.1016/j.catena.2007.12.008

Balesdent, J., Chenu, C., and Balabane, M. (2000). Relationship of soil organic matter dynamics to physical protection and tillage. Soil Tillage Res. 53, 215-230. doi: 10.1016/S0167-1987(99)00107-5

Carroll, E. M., Miller, W. W., Johnson, D. W., Saito, L., Qualls, R. G., and Walker, R. F. (2007). Spatial analysis of a large magnitude erosion event following a Sierran wildfire. J. Environ. Qual. 36, 1105-1111. doi: 10.2134/jeq2006.0466

Certini, G. (2005). Effects of fire on properties of forest soils: a review. Oecologia 143, 1-10. doi: 10.1007/s00442-004-1788-8

Chenu, C., and Plante, A. T. (2006). Clay-sized organo-mineral complexes in a cultivation chronosequence: revisiting the concept of the "primary organo-mineral complex." Eur. J. Soil Sci. 57, 596-607. doi: 10.1111/j.1365-2389.2006.00834.x

Chief, K., Young, M. H., and Shafer, D. S. (2012). Changes in soil structure and hydraulic properties in a wooded-shrubland ecosystem following a prescribed fire. Soil Sci. Soc. Am. J. 76, 1965-1977. doi: 10.2136/sssaj2011.0072

Choromanska, U., and DeLuca, T. H. (2002). Microbial activity and nitrogen mineralization in forest mineral soils following heating: evaluation of post-fire effects. Soil Biol. Biochem. 34, 263-271. doi: 10.1016/S0038-0717(01)00180-8

Christensen, B. T. (2001). Physical fractionation of soil and structural and functional complexity in organic matter turnover. Eur. J. Soil Sci. 52, 345-353. doi: 10.1046/j.1365-2389.2001.00417.x

Conard, S. G., Sukhinin, A. I., Stocks, B. J., Cahoon, D. R., Davidenko, E. P., Ivanova, G. A., et al. (2002). Determining effects of area burned and fire severity on carbon cycling and emissions in Siberia. Climatic Change 55:197. doi: 10.1023/A:1020207710195

DeBano, L. F., Dunn, P. H., and Conrad, C. E. (1977). "Fire's effects on physical and chemical properties of chaparral soils," in Environmental Consequences of Fire and Fuel Management in Mediterranean Ecosystems, eds A. Harold and C. E. Conrad (Washington, DC: USDA), 65-74.

DeBano, L. F., Neary, D. G., and Ffolliott, P. F. (1998). Fire Effects on Ecosystems. New York, NY: John Wiley and Sons.

Eidenshink, J., Schwind, B., Brewer, K., Zhu, Z.-L., Quayle, B., and Howard, S. (2007). A project for monitoring trends in burn severity. Fire Ecol. 3, 3-21. doi: 10.4996/fireecology.0301003

Flessa, H., Amelung, W., Helfrich, M., Wiesenberg, G. L. B., Gleixner, G., Brodowski, S., et al. (2008). Storage and stability of organic matter and fossil carbon in a Luvisol and Phaeozem with continuous maize cropping: a synthesis. J. Plant Nutr. Soil Sci. 171, 36-51. doi: 10.1002/jpln.200700050 this project and contributed to the formulation of the hypothesis, experimental design, and interpretation of results.

\section{FUNDING}

This research was funded by US National Science Foundation, Division of Earth Sciences, Geomorphology, and Land Use Dynamics Program (EAR-1324919 and EAR-1324894).

González-Pérez, J. A., González-Vila, F. J., Almendros, G., and Knicker, H. (2004). The effect of fire on soil organic matter - a review. Environ. Int. 30, 855-870 doi: 10.1016/j.envint.2004.02.003

Guerrero, C., Mataix-Solera, J., Gómez, I., García-Orenes, F., and Jordán, M. M. (2005). Microbial recolonization and chemical changes in a soil heated at different temperatures. Int. J. Wildl. Fire 14, 385-400. doi: 10.1071/WF05039

Hassink, J., and Whitmore, A. (1997). A model of the physical protection of organic matter in soils. Soil Sci. Soc. Am. J. 61, 131-139.

Horn, R., and Smucker, A. (2005). Structure formation and its consequences for gas and water transport in unsaturated arable and forest soils. Soil Tillage Res. 82, 5-14. doi: 10.1016/j.still.2005.01.002

Jenny, H. (1980). The Soil Resources, Origin and Behavior. New York, NY: Springer.

Jian, M., Berli, M., and Ghezzehei, T. A. (2018). Soil structural degradation during low-severity burns. Geophys. Res. Lett. 45, 5553-5561. doi: 10.1029/2018GL078053

Johnson, D., Murphy, J. D., Walker, R. F., Glass, D. W., and Miller, W. W. (2007). Wildfire effects on forest carbon and nutrient budgets. Ecol. Eng. 31, 183-192. doi: 10.1016/j.ecoleng.2007.03.003

Jordan, A., Zavala, L., Mataix-Solera, J., Nava, A., and Alanis, N. (2011). Effect of fire severity on water repellency and aggregate stability on Mexican volcanic soils. Catena 84, 136-147. doi: 10.1016/j.catena.2010.10.007

Kavouras, I. G., Nikolich, G., Etyemezian, V., DuBois, D. W., King, J., and Shafer, D. (2012). In situ observations of soil minerals and organic matter in the early phases of prescribed fires. J. Geophys. Res. Atmos. 117:D12313. doi: 10.1029/2011JD017420

Keeley, J. E. (2009). Fire intensity, fire severity, and burn severity: a brief review and suggested usage. Int. J. Wildland Fire 18, 116-126. doi: 10.1071/WF07049

Knicker, H. (2007). How does fire affect the nature and stability of soil organic nitrogen and carbon? A review. Biogeochemistry 85, 91-118. doi: 10.1007/s10533-007-9104-4

Mataix-Solera, J., Cerdà, A., Arcenegui, V., Jordán, A., and Zavala, L. M. (2011). Fire effects on soil aggregation: a review. Earth Sci. Rev. 109, 44-60. doi: 10.1016/j.earscirev.2011.08.002

Mataix-Solera, J., Gomez, I., Navarro-Pedreno, J., Guerrero, C., and Moral, R. (2002). Soil organic matter and aggregates affected by wildfire in a Pinus halepensis forest in a Mediterranean environment. Int. J. Wildland Fire 11, 107-114. doi: 10.1071/WF02020

Moghaddas, E. E. Y., and Stephens, S. L. (2007). Thinning, burning, and thin-burn fuel treatment effects on soil properties in a Sierra Nevada mixed-conifer forest. For. Ecol. Manage. 250, 156-166. doi: 10.1016/j.foreco.2007.05.011

MTBS (2017). Monitoring Trends in Burn Severity. Available online at: http://www. mtbs.gov/

O'Dea, M. (2007). Fungal mitigation of soil erosion following burning in a semi-arid arizona savanna. Geoderma 138, 79-85. doi: 10.1016/j.geoderma.2006.10.017

Piccolo, A., and Mbagwu, J. S. C. (1999). Role of hydrophobic components of soil organic matter in soil aggregate stability. Water 63:1801. doi: $10.2136 /$ sssaj1999.6361801x

Santos, F., Russell, D., and Berhe, A. A. (2016). Thermal alteration of water extractable organic matter in climosequence soils from the Sierra Nevada, California. J. Geophys. Res. Biogeosci. 121, 1-9. doi: 10.1002/2016JG 003597

Schmidt, M. W., Torn, M. S., Abiven, S., Dittmar, T., Guggenberger, G., Janssens, I. A., et al. (2011). Persistence of soil organic matter as an ecosystem property. Nature 478, 49-56. doi: 10.1038/nature10386 
Scow, K. M., and Alexander, M. (1992). Effect of diffusion on the kinetics of biodegradation: experimental results with synthetic aggregates. Soil Sci. Soc. Am. J. 56, 128-134. doi: 10.2136/sssaj1992.03615995005600010020x

Serrasolsas, I., and Khanna, P. K. (1995). Changes in heated and autoclaved forest soils of S.E. Australia. I. Carbon and nitrogen. Biogeochemistry 29, 3-24. doi: 10.1007/BF00002591

Stoof, C. R., Wesseling, J. G., and Ritsema, C. J. (2010). Effects of fire and ash on soil water retention. Geoderma 159, 276-285. doi:10.1016/j.geoderma.2010.08.002.

Tisdall, J. (1996). "Formation of soil aggregates and accumulation of soil organic matter," in Structure and Organic Matter Storage in Agricultural Soils, eds M. Carter and B. Steward (Boca Raton, FL: CRC Press, LLC). 57-59.

Tisdall, J. M., and Oades, J. M. (1982). Organic matter and water-soluble aggregates in soils. Eur. J. Soil Sci. 33, 141-163. doi: 10.1111/j.1365-2389.1982.tb01755.x

Úbeda, X., and Bernia, S. (2005). "The effect of wildfire intensity on soil aggregate stability in the Cadiretes Massif, NE Spain," in Geomorphological Processes and
Human Impacts in River Basins, eds R. J. Batalla and C. Garcia (International Association of Hydrological Sciences), 37-45.

Urbanek, E. (2013). Why are aggregates destroyed in low severity fire? Plant Soil 362, 33-36. doi: 10.1007/s11104-012-1470-6

Conflict of Interest Statement: The authors declare that the research was conducted in the absence of any commercial or financial relationships that could be construed as a potential conflict of interest.

Copyright (c) 2018 Jian, Berhe, Berli and Ghezzehei. This is an open-access article distributed under the terms of the Creative Commons Attribution License (CC BY). The use, distribution or reproduction in other forums is permitted, provided the original author(s) and the copyright owner(s) are credited and that the original publication in this journal is cited, in accordance with accepted academic practice. No use, distribution or reproduction is permitted which does not comply with these terms. 